\title{
The Socio-Religious Construction: The Religious Tolerance Among Salafi Muslim and Christian in Metro
}

\author{
Dharma Setyawan, ${ }^{*}$ Dwi Nugroho ${ }^{* *}$ \\ *Institut Agama Islam Negeri Metro, Indonesia. Email: dharmasetyawan405@gmail.com, “*Universitas Gadjah Mada \\ Yogyakarta, Indonesia. Email: dwinugroho2020@mail.ugm.ac.id
}

\begin{abstract}
Salafi Islamic community has been negatively constructed as puritan, extreme, and exclusive group separated itself from the social space. This justification precludes possibility that Salafi groups can synergize with surrounding socio-religious conditions. This article reveals the socio-religious life among Salafi community of Ma'had Ittiba'us Salaf in Purwoasri Village, Metro City to maintain the Islamic Salafi concept and expanding network of its followers. The research methodology is qualitative using observation, interviews, and documentation studies to expose the Salafi movement. This study shows that the presence of Salafi in Purwoasri can build good relations with other religious communities, both Muslims and non-Muslims (Chrisrtian). The synergy between Salafi Muslims and Christians in building a strong social construction in maintaining the peace values is facilitated by the FPKM organization. This study concludes that Salafi da'wah is not entirely around the radical activities and leads to violence. Salafis in Metro City use a lot of social networks, technology facilities, and local organizations to preach, be economically, and socially.
\end{abstract}

Keywords: salafi, socio-religious construction, religious relation, tolerance

\section{Konstruksi Sosial-Keagamaan: Toleransi Beragama antara Muslim Salafi dan Pemeluk Agama Kristen di Metro}

\begin{abstract}
Abstrak
Pandangan masyarakat tentang komunitas Islam Salafi telah terkonstruksi negatif sebagai kelompok puritan, ekstrim, dan eksklusif yang memisahkan dari lingkungan sosial. Justifikasi tersebut menutup kemungkinan Salafi dapat bersinergi dengan keberagaman sosial-keagamaan sekitarnya. Artikel ini bertujuan untuk mengungkap realitas kehidupan sosial-keagamaan komunitas Salafi Ma'had Ittiba'us Salaf di Kelurahan Purwoasri Kota Metro dalam mempertahankan konsep Islam Salafi dan memperluas jaringan pengikutnya. Metodologi penelitian ini adalah kualitatif dengan menggunakan data observasi, interview, dan studi dokumentasi untuk menjelaskan gerakan Salafi. Penelitian ini menunjukkan bahwa keberadaan Salafi di Purwoasri mampu membangun hubungan baik dengan komunitas kegamaan lainnya, baik Muslim maupun non-Muslim (Kristen). Sinergisitas antara Salafi dan Kristen dalam membangun konstruksi sosial yang kuat dalam menjaga nilai-nilai perdamaian difasilitasi dengan adanya Paguyuban FPKM. Penelitian ini menyimpulkan bahwa ternyata dakwah Salafi tidak secara keseluruhan terkonsentrasi dengan aktivitas radikal dan mengarah kepada kekerasan. Salafi di Kota Metro banyak menggunakan jaringan sosial, fasilitas teknologi, dan bergabung dalam Paguyuban untuk berdakwah, berekonomi, dan bersosial. Artikel ini masih terbatas pada skala penelitian di Kota Metro, sehingga masih sangat mungkin untuk dilengkapi oleh kajian pada tempat lain dengan skala dan pendekatan yang berbeda.
\end{abstract}

Kata Kunci: salafi, konstruksi sosial-kegamaan, relasi keagamaan, toleransi

* Naskah diterima Agustus 2021, direvisi September 2021, dan disetujui untuk diterbitkan November 2021

Dialog, 44 (2), 2021, 190-203

https://jurnaldialog.kemenag.go.id,p-ISSN: 0126-396X, e-ISSN: 2715-6230

This is open access article under CC BY-NC-SA-License

(https://creativecommons.org/license/by-nc-sa/4.0/)

Dialog Vol. 44, No.2, Desember 2021

190 


\section{A. Pendahuluan}

Generalisasi tentang Islam Salafi sebagai kelompok Islam ekstrimis, radikal, dan intoleran (Rahmatullah, 2017) telah menguatkan tembok pemisah antara kelompok Salafi dan kelompok agama lainnya. Sebagian besar, publik menganggap keberadaan Muslim Salafi sebagai ancaman dalam waktu dekat maupun panjang (Norlen, 2020). Justifikasi ini telah menciptakan gelombang kebencian terhadap kelompok Salafi dan membatasi interaksi satu sama lainnya. Asumsi tersebut tidak relevan dengan realitas sosialkeagamaan yang terbangun di kelompok Islam Salafi Ma'had Ittiba'us Salaf kota Metro. Gerakan mereka lebih menunjukkan kehidupan yang humanis, toleran, dan terbuka dengan ruang sosial dan keagamaan, baik sesama umat Islam maupun lintas agama, meskipun dalam beberapa aspek masih menonjolkan kehidupan yang puritan, misal dalam kegiatan ibadah. Gerakan dakwah kelompok Salafi pada prinsipnya, sejak masa Nabi, terbangun dari argumentasi kritis, konstruktif, dan moderasi (Solahudin, 2019). Kondisi kehidupan Salafi di atas menunjukkan identitas dakwah toleran dan anti kekerasan seperti apa yang menjadi dasar konsep Wahabi dalam dakwah yaitu toleransi beragama dan anti kekerasan (Rohmaniyah and Woodward, 2012).

Salafi (Griffel, 2015; Meijer, 2009) merupakan sebuah kelompok Muslim yang banyak menisbahkan ajarannya kepada ajaran Wahabi dengan mengajak kepada kemurnian Islam dalam pemahaman dan praktek, sesuai dengan ajaran Salafush Shalih. Sebagai gerakan Islam puritan dengan menyeru pada kemurnian dan menolak bentuk ajaran-ajaran bid'a (Wiktorowicz, 2000; 2001) telah meneguhkan kedudukan Islam Salafi pada konservatisme; memisahkan dari intervensi negara; dan eksklusif sebagai kelompok Islam yang meneladani para pendahulu yang saleh dengan menolak penemuanpenemuan modern, konsep hukum negara, dan hak-hak perempuan (Yakin, 2018).

Kehidupan sosial dan keagamaan (kelompok) Salafi digambarkan sebagai kelompok konservatif dengan menerapkan nilai-nilai Islam yang relevan dengan ajaran terdahulu (Brown, 2015). Islam Salafi membawa ajaran yang memiliki tendensi kuat pada ajaran-ajaran kemurnian. Oleh sebab itu, perbenturan dengan kebudayaan lokal sering membuat gerakan Salafi mendapatkan penolakan secara sosial maupun keagamaan. Secara struktur sosial, keberadaan kelompok ini telah menjadi perbincangan publik karena posisi dan bentuk ajarannya digolongkan sebagai ajaran yang tidak mampu melebur dengan kebudayaan lokal, bahkan menentangnya dengan keras.

Islam merupakan agama yang menyeru pada hal yang baik lagi damai, menjawab penderitaan manusia, dan meningkatkan produktivitas (Omelicheva, 2016). Sebagai sebuah gerakan non-revolusioner, kelompok Islam Salafi memiliki tujuan besar dalam pergerakan dakwahnya yaitu mengislamkan orang-orang yang tidak memiliki pemahaman literal dan menggugat pemahaman ritual dari kaum tradisionalis (Jahroni, 2018). Pemahaman tersebut disandarkan kepada ulama-ulama Timur Tengah dengan menggunakan media dakwah berbasis website, outlet, majalah yang berafiliasi dengan YPI al-atsary (Chaplin, 2018a). Jika diperhatikan, pergerakan Salafi tidak lagi hanya berfokus pada gerakan jihad yang dimaknai dengan perang (Salafi jihadis), melainkan lebih mengarah pada hal-hal yang dapat diterima masyarakat, seperti dakwah melalui media sosial, masuk ke dalam lembaga pendidikan umum, dan majlis ta'lim. Usaha-usaha ini cepat atau lambat memberikan dampak positif terhadap gerakan Salafi di masa depan.

Studi sebelumnya tentang komunitas Islam Salafi telah banyak dilakukan oleh para ahli. Penelitian-penelitian tersebut di antaranya mengungkap keberadaan Islam Salafi yang cenderung menimbulkan pergejolakan seperti aksi terorisme (Staunton, 2008), ekstrimisme (Hellmich, 2008), radikal (Abdullah and Salleh, 2015), dan menolak hukum selain Islam dan yang 
dipercayainya (Wilonoyudho, Salim and Muhtaram, 2020). Gambaran tentang kelompok Salafi tersebut membentuk sebuah frame negatif dari publik bahwa keberadaan mereka telah mengancam nilainilai sosial-keagamaan umat Muslim dan agama lainnya. Secara global, isu-isu konservatif kelompok Salafi terus bergulir di kalangan masyarakat sehingga menyebabkan akses sosial-keagamaan tertutup karena terbatas pada kelompokkelompok fanatismenya (Umar and Woodward, 2020). Generalisasi keberadaan Salafi dengan stigma negatif (Redjosari, 2019) sering menimbulkan konflik-konflik horizontal transnasional (Wagemakers, 2018) yang membuat publik terus menerus mendeskreditkan keberadaan mereka. Salafi juga tidak terlepas dari persitegangan di kalangan internal dengan alasan masingmasing (Sunarwoto, 2016). Untuk melihat kontekstualitas kehidupan kelompok Salafi, artikel ini akan berfokus pada aspek-aspek socio-religious Salafi dengan lebih komprehensif.

Artikel ini bertujuan untuk menjawab pertanyaan bagaimana hubungan Islam Salafi dan pemeluk agama Kristen terkonstruksi secara sosiologis-religious sehingga menciptakan spirit kebersamaan. Keberadaan kelompok Islam Salafi tidak sepenuhnya mengalami penolakan. Mereka di sisi lain juga mampu melebur dengan realitas sosial masyarakat (Setiawan and Midia, 2020). Namun asumsi global tentang Salafi membuat kelompok ini sulit membangun interaksi karena dikenal sebagai varian Islam puritan (Wahib, 2017) dengan menolak segala bentuk moderasi Islam, sosial, pendidikan, dan politik. Kecenderungan pandangan ini menjadi alasan kuat untuk menggolongkan Islam Salafi sebagai kelompok ekstrimis yang menolak adanya konsep sosialisme religious.

Pemahaman publik tentang Islam Salafi secara global mengkonstruksi keberadaan kelompok Salafi lainnya yang berada di daerah-daerah tertentu. Realitas sosial tersebut membuat komunitas Salafi mendapat penolakan di berbagai tempat
(Nurish, 2020). Salafi pada prinsipnya memiliki nilai kedirian yang kuat, namun di sisi lain juga memiliki etika keagamaan modern untuk mengakomodasi kehidupan bersama sebagai subjektivitas Salafi (Chaplin, 2020). Untuk meminimalkan pergesekan antar elemen dan kelompok Islam maupun agama lainnya, beberapa kelompok Salafi juga melakukan integrasi dengan kelompok dan elemen komunitas setempat (Abidin and Hafizah, 2019). Selain itu, mereka telah berkembang dan mampu melakukan peleburan dengan nilai-nilai nasionalisme, meskipun mereka juga mengedepankan norma-norma Islam dan mengabaikan dogma-dogma non-Islam (Chaplin, 2018).

\section{B. Metode Penelitian}

Penelitian ini menggunakan metode survei yang dilakukan pada sebuah komunitas Islam Salafi di kelurahan Purwoasri, Kota Metro sebagai ruang sosial keagamaan Salafi pada tahun 2021. Penelitian ini berjenis penelitian lapangan dengan mengambil sudut pandang pihak ketiga. Metode ini memberi ruang terbuka bagi peneliti untuk melihat sebuah kondisi lebih komprehensif dengan kacamata fenomenologi. Phenomenology is the study of lived, human phenomena within the everyday social context in which the phenomena occur from the perspective of those who experience them (Titchen \& Hobson, 2005).

Untuk menghindari bias informasi, penelitian ini menggunakan metode pendekatan social construction of reality, yaitu sebuah metode untuk melihat sebuah proses kejadian yang terjadi secara terus-menerus. Konsep penelitian ini menggunakan desain penelitian kualitatif-deskriptif. Artinya penelitian ini menggambarkan sebuah peristiwa yang tidak hanya bersifat tunggal namun juga mencoba mendeteksi hubungan di antaranya. Peneliti dalam proses ini aktif dalam aktivitas masyarakat dengan tujuan untuk mendapatkan sebuah informasi yang credible.

Pengumpulan data dilakukan dengan beberapa cara, pertama, observasi yang dilakukan oleh peneliti untuk melihat 
rutinitas kehidupan Salafi sejak tahun 2017 satu tahun setelah dibentuknya komunitas FKPM bersama dengan komunitas Islam Salafi, pemeluk agama Kristen, dan organisasi masyarakat lainnya, seperti NU dan Muhammadiyah. Kedua, pengumpulan data diambil dari proses interview dengan kelompok Islam Salafi dengan jumlah 8 orang sebagai representasi mayoritas komunitas Salafi, ketua FKPM, tokoh agama Salafi, dan pihak kepolisian pada tahun 2017 dan 2021. Sebagai upaya pendekatan, metode wawancara yang digunakan adalah semi terstruktur dengan menanyakan pertanyaan-pertanyaan yang sebelumnya telah disusun. Selain itu, dalam penelitian ini juga melakukan studi dokumentasi untuk memperkuat posisi peneliti dan kelengkapan data sejak 2017.

Tahap awal dalam penelitian ini adalah penjabaran dari sebuah rumusan masalah yang dituangkan ke dalam pertanyaanpertanyaan yang akan diajukan kepada sumber primer. Kemudian dilanjutkan dengan menentukan sampel dengan menggunakan metode simpel sampling. Metode ini ditujukan untuk menentukan sampel data sesuai dengan kebutuhan dalam penelitian. Dalam proses pengumpulan data, peneliti menggunakan metode semi terstruktur. Setelah tahaptahap tersebut sudah dilakukan, proses selanjutnya adalah melakukan cek kevalidan data dan melakukan triangulasi.

Dalam proses analisis data, peneliti menggunakan tiga proses yang harus dilakukan. Proses ini terdiri dari penyusunan, pengkategorian, dan pengolahan data. Dengan menggunakan metode pendekatan fenomenologi dan konstruksi sosial, analisis data berlangsung pada saat penelitian sedang berjalan. Metode triangulasi digunakan untuk melakukan sebuah analisa dengan membenturkan dengan sebuah data yang terhimpun dari variabel lainnya. Metode yang digunakan lebih kepada deskripsianalisis dengan menangkap sebuah informasi, realitas sosial, dan kejadiankejadian secara sistematis.

\section{Hasil dan Pembahasan \\ Interaksi Sosial sebagai Ruang Dakwah Salafi}

Din Wahid membagi kelompok Salafi yang berkembang di Indonesia menjadi tiga kelompok besar, yaitu Purits, Haraki, dan Jihadist (Wahid, 2015). Salafi Purits (ICG, 2004) berarti kelompok Salafi yang dalam ajarannya mengajak untuk memurnikan agama dengan cara damai, bergerak dalam sektor pendidikan, dan melakukan pengasingan sebagai sebuah metode dakwah. Sedangkan Salafi Haraki (politicos) merupakan kelompok Salafi yang bergerak dalam bidang perpolitikan karena mereka menganggap bahwa politik diperbolehkan dengan tujuan pemurnian Islam. Berbeda dengan dua kelompok Salafi di atas, kelompok Salafi Jihadis lebih ektrim dalam menyerukan kemurnian agama yaitu dengan cara kekerasan dan revolusi. Meskipun ketiga faksi tersebut memiliki metode berbeda dalam berdakwah, mereka memiliki kesamaan keyakinan tentang Islam bahwa Islam yang saat ini berkembang di berbagai negara telah keluar dari nilai-nilai murni Islam (Wiktorowicz, 2006).

Dakwah yang dilakukan oleh kelompok Salafi di Kota Metro memunculkan realitas yang berbeda dengan Salafi pada umumnya. Khususnya Salafi Jihadits (Wahid, 2015) yang di berbagai tempat mendapatkan penolakan karena dinilai radikal, sesat, dan ekstrim yang tidak sesuai dengan nilai-nilai Islam yang damai, teduh, dan penuh kebersamaan (Redjosari, 2019). Penolakan juga dilakukan dengan upaya-upaya politik untuk mengalienasi keberadaan mereka (Saalfeld, 2019). Hal yang berbeda terjadi pada saat komunitas Salafi mampu mengubah model dalam berdakwah. Meskipun belum sepenuhnya, misalnya, merebaknya pengguna pakaian syar'i dalam trend hijrah (Zaenuri and Yusuf, 2019a), membuka akses Salafi untuk masuk ke lingkungan masyarakat. Keberadaan mereka membuka peluang untuk terjalinnya interaksi dalam pendidikan agama (Pall and Pereiro, 2020), kajian-kajian sunah, khutbah jumat, dan ketersediaan publik mengundang ustadz Salafi dengan lebih 
mengarah pada tema umum (Nashirudin, 2017). Peran perempuan Salafi dalam berdakwah melalui fashion juga tidak dapat dipungkiri mampu mentranslokalkan pakain-pakaian syar'i yang diminati anak muda hijrah yang up to date dan kekinian (Mahanani, Abdullah and Noviani, 2019).

Perubahan model dakwah yang dilakukan komunitas Salafi yang lebih bersifat kontemporer dengan lebih melihat konteks agar keberadaan mereka dapat diterima oleh konsep sekuler dan demokratis menjadi salah satu upaya untuk melakukan sinergi dengan kondisi sekitar (Othman Alkaff and Bin Jani, 2021). Interaksi menjadi salah satu jalan untuk menghubungkan kelompok Salafi dengan kelompok lainnya, sebagai individu maupun sebagai kelompok. Ivo, sebagai perempuan Salafi baru, mengaku bahwa awalnya dia bukanlah seorang yang terlahir sebagai generasi Salafi, melainkan karena interaksi yang berjalan masif membuatnya tertarik dengan konsep ber-Islam Salafi dan masuk ke dalam kelompok Salafi melalui jalan pernikahan (Ivo, 2021). Fenomena ini menunjukkan bahwa sikap eksklusivitas di dalam lingkungan Salafi tidak terbukti karena telah terbangunnya interaksi sosial yang baik dengan masyarakat sekitar. Di sisi lain, meskipun kelompok Salafi mencoba mempertahankan proses puritanisme, perkembangan teknologi justru membuat komunitas Salafi mampu masuk ke dalam realitas sosial kelompok lainnya. Begitu juga menurut Emi, selaku perempuan Salafi, mengungkapkan bahwa pemanfaatan media sosial untuk keperluan sosial dan dakwah tidak bertentangan dengan normanorma syariat. Dalam arti, pemanfaatan media sosial dalam berdakwah tidak mendegradasi nilai-nilai syariat. Pada saat yang sama, Muslim diminta untuk terus berinovasi dan berkembang dengan ilmu pengetahuan, namun tetap berpegang teguh pada prinsip-prinsip keagamaan (Emi, 2021). Kelompok Islam Salafi secara tidak langsung mendapat kemudahan berupa akses untuk menjangkau publik yang lebih luas, sehingga berpengaruh pada sistem sosial keagamaan lainnya.
Dakwah melalui media sosial menjadi hal positif untuk meraih argumen masyarakat. Media sosial pada tahap ini menjadi jembatan dakwah Salafi yang dikemas melalui praktik-praktik sosial berbasis keagamaan (Nurani, 2019). Pemanfaatan media sosial mampu memberi dampak signifikan dalam membentuk pola pikir anak-anak muda terkait Islam (Halim, 2015; Taufik and Taufik, 2020). Fenomena hijrah yang juga dilakukan oleh kalangan artis (Zaenuri and Yusuf, 2019) perlahan mampu mengambil perhatian publik melalui fashion yang digunakan, pola kehidupan keluarga, dan rutinitas dalam skala sosial, ekonomi, dan pendidikan. Dalam hal pemanfaatan media sosial, Gion, tokoh agama Islam Salafi mengungkapkan bahwa fasilitas media sosial dapat diibaratkan sebagai pisau bermata ganda. Sepanjang penggunaannya diniatkan karena ibadah dan memberi manfaat bagi umat tentu tidak ada masalah. Namun jika sebaliknya maka itu yang menjadi permasalahan (Gion, 2021). Dengan memanfaatkan ruang-ruang internet, kanalkanal media, dan konten grafis membuat dakwah Islam melalui media sosial dan media massa semakin beragam dan mudah dilakukan (Saepullah, 2020). Gerakan dakwah model ini banyak dilakukan oleh kalangan Salafi Puritis (ICG, 2004) dengan mengajak atau berdakwah dengan cara damai.

Paham Salafi banyak menyebar ke berbagai negara melalui proses transnasionalisasi, pertukaran pelajar di beberapa perguruan tinggi di Saudi Arabia dan masifnya dana-dana sosial yang digelontorkan oleh lembaga amal untuk mendorong pergerakan Salafi (Hasan, 2006). Melalui proses integrasi dengan dunia pendidikan, dakwah Salafi mulai mendapat ruang untuk mengajak pada pemahaman tentang konsep Islam murni dari anak muda (Saparudin, 2017). Sedangkan dalam konsepsi Majelis Ta'lim, sinergisitas dakwah Salafi dengan konsep Islam lainnya mulai menuai hasil positif. Mulai dari kajian-kajian sunah, khutbah Jumat, dan kajian ta'lim yang diisi oleh ustadz Salafi menunjukkan 
keterbukaan publik untuk mendengar dan mengaji tentang konsep-konsep Islam (Nashirudin, 2017).

Terjalinnya ikatan sosial dalam upayaupaya seragam untuk bersinergi menciptakan daerah aman dari kriminalisasi membawa pada terbentuknya hubungan baik lintas agama. Interaksi yang intens ini dimulai sejak didirikannya komunitas kemitraan polisi dan masyarakat sejak tahun 2016 yang beranggotakan 80 orang (Salafi, NU, Muhammadiyah, dan Kristen). Suyono, selaku ketua FKPM (Forum Kemitraan Polisi dan Masyarakat, bukan dari kelompok Salafi dan Kristen) kelurahan Purwoasri menjelaskan bahwa keberadaan kelompok Islam Salafi sejauh ini mampu berkolaborasi dengan kelompok Islam lainnya dan pemeluk agama Kristen. Dalam situasi pemolisian masyarakat, kelompok Salafi mampu membaur dan berhubungan baik dengan kelompok Islam lainnya dan juga dengan umat Kristiani yang hidup bersebelahan dengan memanfaatkan fasilitas teknologi Handy Talky (HT). Keberadaan mereka mampu membentuk sebuah kekuatan lokal untuk menciptakan keamanan (Suyono, 2017).

Pemanfaatan fasilitas ini pada akhirnya menjadi bagian penting dari membangun nilai-nilai solidaritas, hubungan baik, berkolaborasi dalam pengamanan dari tindak kriminalitas dan silaturahmi antar warga. Suyono menjelaskan bahwa keberadaan fasilitas radio ini mampu menyatukan warga yang beragama Kristiani dan Muslim Salafi dengan warga muslim lainnya sejak inisiasi forum kemitraan masyarakat terbentuk pada 2016 hingga saat ini. Kondisi ini jelas berbeda dengan ikatan sosial-keagamaan di Barat yang menekankan untuk menjaga jarak dan hanya berhubungan baik dengan yang seiman, seagama, dan seideologi (Leszczensky and Pink, 2017). Begitu pun perempuan Muslim cenderung memisahkan diri dari kalangan non-Muslim dan anak muda non-Muslim sebaliknya tidak menjalin ikatan sosial dengan pemuda Muslim (Kretschmer and Leszczensky, 2021). Pola ini mendasari terbangunnya segregasi sosial di kalangan Muslim dan non-Muslim.

Kelompok Salafi yang sebelumnya dikenal sebagai kelompok yang keras, menentang modernitas, pada saat yang sama menggunakannya sebagai media dakwah dan berinteraksi dengan dunia luar. Fenomena ini terjadi di komunitas Salafi Ma'had Ittiba'us Salaf Purwoasri Kota Metro. Dengan menggunakan pendekatan sosial-keagamaan dan pengoptimalan fasilitas digital, Salafi mampu mengubah stigma bahwa mereka merupakan kelompok yang keras, menutup diri, dan menimbulkan persitegangan, meskipun dalam beberapa aspek tetap mempertahankan identitas keagamaannya.

\section{Social-Religious dan Digitalisasi Dakwah}

Greg G. Armfield (Armfield and Holbert, 2003) menjelaskan bahwa keberadaan internet akan menghilangkan pola-pola tradisionalitas agama. Argumentasinya sangat mendasar bahwa orang yang semakin religius maka akan cenderung menghindari internet sebagai produk modernitas. Namun, keberadaan media sosial yang berkembang secara berkelanjutan dewasa ini faktanya telah menjadi bagian dari dakwah Islam Salafi, yang mana fasilitas ini justru mampu menjangkau banyak tempat dan manusia (Nurdin, 2016). Perkembangan industri 4.0 (Kagermann H.; Wahlster, W.; Helbig, 2013; Kagermann, Wahlster and Helbig, 2013) pada abad ke 20 mempermudah gerakan dakwah Salafi untuk menjangkau individuindividu yang pada awalnya tidak memiliki relasi dan jaringan dengan mereka melalui dialog-dialog online yang memperkaya pemahaman tentang kemurnian ajaran Islam yang ditawarkan komunitas Salafi (Becker, 2009). Keberadaan teknologi membuat dakwah menjadi lebih bervariasi, seperti dakwah melalui konten grafis: penyebaran dakwah Salafi melalui gambar, tulisan, dan juga video. Misalnya, dakwah melalui Youtube, meskipun tidak sepenuhnya memberikan nilai penuh, dakwah seperti ini justru mudah diterima oleh publik (Arifin, 2019). 
Secara konsep keagamaan, Salafi merupakan kelompok puritan, namun keberadaannya telah menciptakan persinggungan-persinggungan, sehingga menyebabkan tidak harmonisnya hubungan antar sesama manusia dalam beragama. Pada akhirnya penolakan terhadap Islam Salafi tidak hanya dirasakan oleh kelompok Salafi melainkan juga orang-orang yang juga mempelajari ajaran Salaf, seperti pondok pesantren berbasis pengajaran Salaf (Kusmanto, Fauzi and Jamil, 2015). Generalisasi antara Islam Salafi dengan pondok pesantren berbasis ajaran Salaf telah berdampak pada eksistensi Pondok Pesantren Salaf. Artinya penolakan terhadap Salafi telah membawa dampak pada kehidupan masyarakat yang lainnya secara sosial-keagamaan dan kebudayaan.

Meskipun demikian, Salafi pada prinsipnya juga menggunakan cara-cara damai dan relevan, baik secara sosial maupun keagamaan (Abidin and Hafizah, 2019), seperti menggunakan fasilitas digital (Amin, 2020), berafiliasi dengan kampus (Chaplin, 2018), dan mengoptimalkan peran perempuan Salafi dalam berdakwah (Nurani, 2019).

"Membantu orang yang membutuhkan adalah kewajiban bagi umat Islam selama mempunyai kemampuan" (Riko Wardana, sebagai anggota Muslim Salafi, 2021).

Interaksi sosial-keagamaan merupakan aktivitas yang tepat untuk menyerukan kebaikan dan menciptakan kesepakatan bersama (Wiktorowicz, 2005) untuk melegitimasi bahwa Islam tidak membedabedakan individu yang satu dengan lainnya. Keberadaan Salafi juga dapat melebur dengan pluralitas masyarakat sebagai sebuah kelaziman, seperti apa yang terjadi di Albania, bahwa tidak ada penentangan tentang lokalisasi dengan dibudayakan dan dinasionalisasikan kembali (Kursani, 2018).

Kehadiran para artis yang turut dalam gelombang hijrah telah membawa dampak positif pada gerakan Salafi (Zaenuri and Yusuf, 2019). Melalui metode soft movement dengan memanfaatkan media sosial, trend hijrah dan membangun hubungan baik dengan lingkungan, Salafi mampu menarik simpatisan masyarakat. Tidak jarang anakanak muda mulai tertarik untuk mempelajari konsep berislam yang murni, dengan mengamalkan sunah-sunah dan menghindari bid'a.

Salafi pada dasarnya bukanlah sebuah gerakan yang menolak modernitas melainkan mencoba untuk mengkombinasikan antara modernitas dengan konteks Islam yang otentik (Duderija, 2007). Berkembangnya fasilitas teknologi membuat dakwah Salafi dapat bekerja lebih optimal dalam menyebarkan informasi-informasi tentang Islam. Gerakan dakwah mereka juga bervariasi, tidak monoton membicarakan aspek-aspek teologi melainkan dapat memasukkannya dalam aktivitas sosial maupun dalam aktivitas ekonomi. Dalam gerakan sosial baru, Salafi mampu menyentuh ruangruang sosial tertentu, bahkan dapat berinteraksi aktif dengan menggunakan fasilitas teknologi tanpa mengkhawatirkan mendapat penolakan dari kelompok masyarakat tertentu. Selain itu, media sosial memberikan ruang yang terbuka untuk melakukan aktivitas dakwah di bidang ekonomi, sehingga gerakan Salafi akan mudah diterima secara perlahan. Ibu Hafzah, Mbak Zahra, dan Bapak Riko Wardana selaku muslim Salafi mengakui hal tersebut bahwa pemanfaatan teknologi dalam aktivitas sosial-ekonomi mereka dapat menyentuh kepribadian seseorang. Hal tersebut dimanfaatkan untuk mendakwahkan ajaran-ajaran Salafi secara bertahap. Keuntungan yang didapatkan selain berupa finansial, aktivitas ini juga menjadi awal mula dakwah Salafi masuk di lingkungan masyarakat (Hafzah, Zahra, dan Riko Wardana, 2021).

\section{Relasi antara Salafi-Kristen sebagai Toleransi Beragama}

Dalam kajian agama, Emile Dhurkheim mendefinisikan agama sebagai sebuah kekuatan yang mampu membuat orang mempunyai kesamaan emosional. "Religion is a unified system of beliefs and practices relative to sacred things, that is to say, this set apart and forbidden - beliefs and practices which unite into 
one single moral community called a church, all those who adhere to them" (Horii, 2019; Dhurkheim, [1912], 1995).

Pada abad ke-20 saat ini pergerakan Muslim Salafi di Kota Metro menunjukkan trend positif karena mampu menciptakan sebuah ruang interaksi dengan warga sekitar, baik dalam aktivitas keagamaan, pendidikan, ekonomi, dan aktivitas lainnya dalam membentuk moral komunitas. Mereka mampu hidup berdampingan meskipun memiliki corak yang berbeda dalam paham, ideologi, dan konsep beragama.

Keberadaan komunitas Salafi yang heterogen membuat interpretasi tentang konsep Salafi sering berbeda yang terkadang disesuaikan dengan realitas sehari-hari (Damir-Geilsdorf, Menzfeld and Hedider, 2019), bahkan mereka (Salafi) sering berkontestasi untuk mendapatkan sebuah pengakuan sebagai komunitas Salafi yang murni dari Salafi pusat (Sunarwoto, 2016). Secara pendidikan anak-anak muda Salafi mulai terbuka dengan pendidikan umum, dari segi ekonomi kelompok Islam Salafi mulai memiliki akses keluar dalam melakukan ekspansi, dan dalam ikatan sosial Salafi mulai menjalin hubungan baik dengan Islam lainnya serta agama non Muslim (Kristen). Konsep dakwah seperti ini sejalan dengan interpretasi konsep alwara wa al bara dari Wasati yang lebih berfokus pada pengajakan masuk Islam dengan cara-cara yang lembut dan mudah diterima secara nalar-logika dan menilai seseorang dari personalitinya terhadap Muslim (Shavit, 2014).

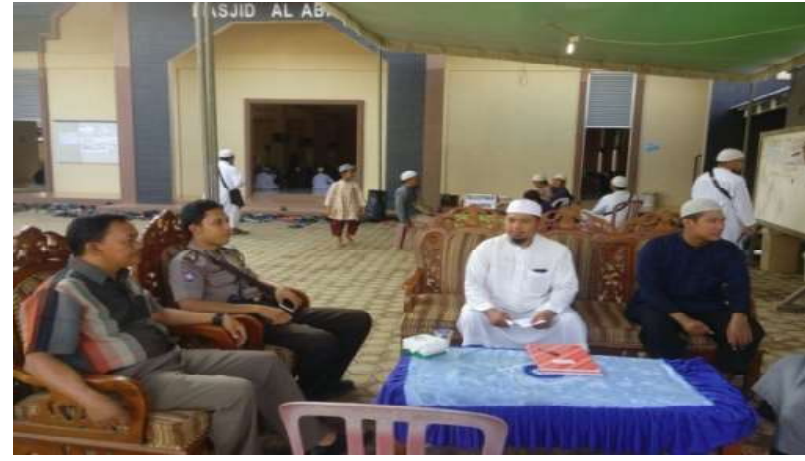

Dokumentasi warga pada pengamanan acara Dauroh di Pondok Pesantren Ittiba'us Salaf oleh FKPM, Polisi Masyarakat dan jamaah Kristiani
Terbentuknya komunitas (Paguyuban) Purwoasri Bersatu pada tahun 2016 membuat hubungan baik antara Islam (Salafi, NU, dan Muhammadiyah) dan Kristen berjalan baik. Bekerjasama dengan Polisi masyarakat, komunitas ini dinamai dengan Forum Kemitraan Polisi dan Masyarakat (FKPM).

Suyono sebagai ketua forum menjelaskan bahwa keaggotaan komunitas ini berjumlah sekitar 80-an anggota yang berasal dari masyarakat Kristen, Salafi, dan ormas Muslim lainnya. Keberadaan mereka mampu berkolaborasi membentuk sebuah kekuatan bersama. Suyono secara sederhana menjelaskan bahwa:

"Komunitas ini secara bergantian melakukan pemolisian tempat, misalnya pada acara Natal maka seluruh anggota melakukan penjagaan agar acara Natal berjalan dengan damai dan khitmad. Begitu pun jika ada acara di kalangan Muslim Salafi, Muhammadiyah dan NU, secara bersama-sama komunitas ini akan mengkondusifkan tempat. Proses solidaritas ini terus berjalan di hari-hari biasa untuk menjaga ketertiban dan keamanan" (Suyono, 2021).

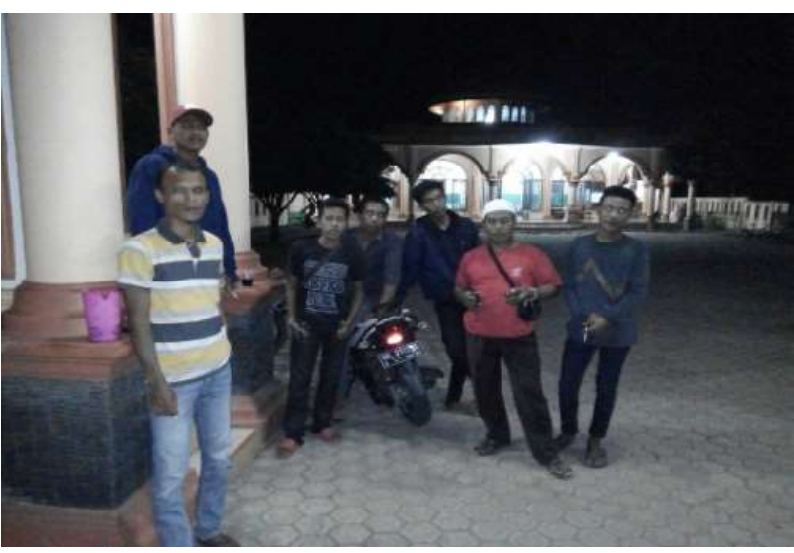

Dokumentasi warga pada pengamanan pada malam Tarawih dari umat Kristiani, FKPM, dan Polisi masyarakat

Gerakan ini menjadi upaya untuk meningkatkan kepercayaan masyarakat bahwa keberadaan Islam Salafi tidak menciptakan gejolak negatif, melainkan positif dalam pengajaran Islam dan lingkungan sosial. Upaya tersebut 
merupakan modal sosial yang kuat dalam membangun sebuah peradaban. Lin (Lin, 2019) menjelaskan modal sosial ke dalam teori "The Neo Capital Theories". Berbeda dengan Bourdieu (Bourdieu, 2018) dan putnam (Putnam, 2001), Lin lebih melihat modal sosial sebagai upaya individu/ kelompok dalam mengakses sumber daya sosial yang sejauh ini tersimpan dan jarang teroptimalkan. Sumber daya ini akan sangat bermanfaat untuk memperkuat eksistensi individu maupun kelompok.

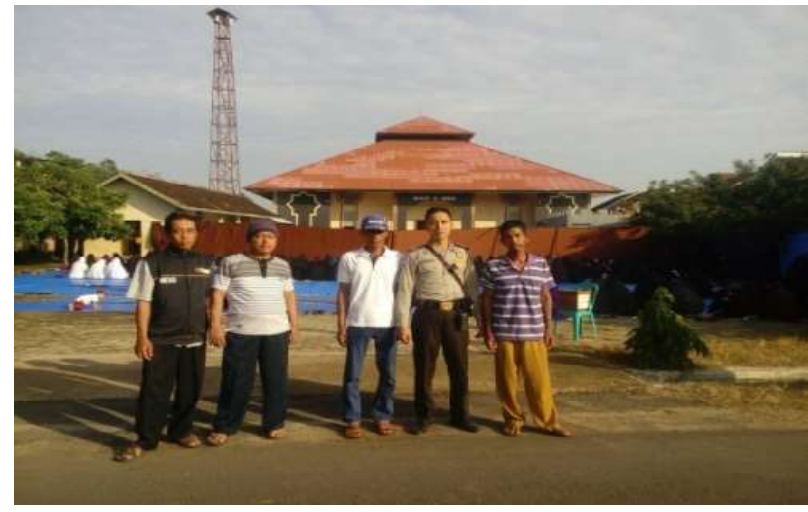

Dokumentasi warga pengamanan pada Ibadah Salat Idhul Adha dari umat Kristiani dan Polisi masyarakat

\section{Supandi, selaku anggota} Babinkamtibmas keluarahan Purwoasri, menjelaskan bahwa perbedaan kepercayaan sejauh ini tidak menjadi alasan untuk memisahkan diri dari pergumulan sosial antara Salafi, umat Muslim lainnya dan Kristiani. Mereka menyadari bahwa sinergi menjadi modal kuat untuk menjaga satu sama lainnya. Misalnya pada saat ibadah salat Tarawih, umat Kristen melakukan penjagaan di rumah-rumah warga Muslim, sehingga mereka yang sedang melakukan ibadah tarawih dapat menjalankannya dengan khusuk (Supandi, 2017).

"Solidaritas dalam Islam bukan hanya dalam bentuk ekonomi, melainkan dalam segala hal. Karena kita sebagai manusia diperintahkan untuk saling tolong menolong dalam hal kebaikan" (Yusuf, 2021).

Aktivitas ini terbangun atas dasar kesadaran sosial untuk saling mendukung aktivitas keagamaan dan keamanan lingkungan. Dengan membentuk sebuah Paguyuban interaksi terbangun dengan baik dan saling support atas aktivitas sosialkeagamaan. Kontekstualitas dalam beragama mewajibkan setiap pengikutnya memahami konteks dalam berdakwah.

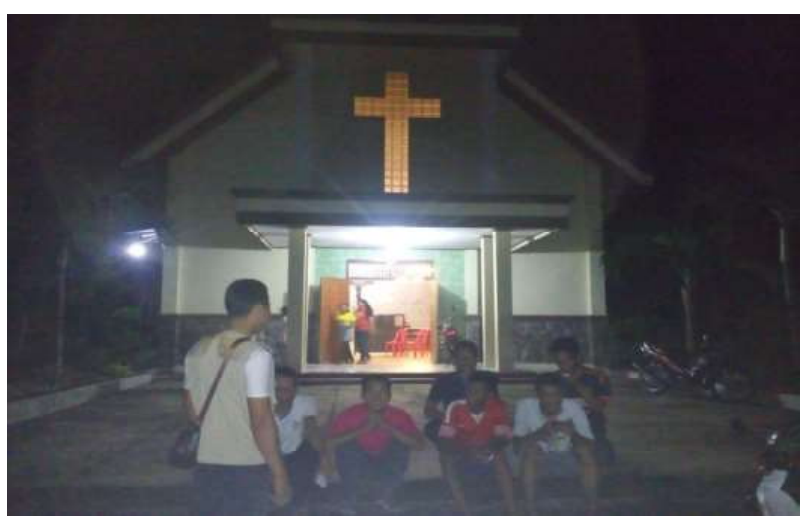

Dokumentasi warga pada pengamanan malam Hari Raya Natal

Kesesuaian dengan konteks sosialkeagamaan membuat Salafi di Albania mampu membangun hubungan baik dengan kepercayaan lain. Hubungan ini terjalin dari kemampuan Salafi yang dapat melebur dengan pluralitas masyarakat dan lokalisasi agama (Kursani, 2018). Begitu pun realitas sosial-keagamaan Salafi yang terjadi di Singapura, mereka melakukan sinergi dengan konsep sekuler dan demokratis yang banyak berkembang di sana (Othman Alkaff and Bin Jani, 2021). Salafi pada dasarnya juga berkembang dengan melakukan peleburan ideologi dengan nilainilai nasionalisme, meskipun keberadaannya tetap memprioritaskan norma-norma Islam daripada non-Muslim (Chaplin, 2018).

Komunikasi yang terbangun baik ini memberi gambaran bahwa Islam Salafi tidak membatasi diri dalam aktivitas komunal. Terjalinnya hubungan positif dengan masyarakat non Muslim menunjukkan bahwa Salafi bukan kelompok ekstrim, membatasi diri, dan konservatif secara total. Keberadaan media sosial dalam proses ini sangat membantu proses sosial terbangun dengan baik tanpa menimbulkan pergesekan antara kelomok Islam Salafi dan Kristen yang hidup berdampingan. 
Penelitian ini menunjukkan bahwa anggapan publik terkait eksklusivitas dan konservatisme Salafi tidak terbukti. Terjalinnya hubungan baik dengan Muslim lainnya dan umat Kristiani menunjukkan bahwa komunitas Salafi sangat terbuka. Mbak Ivo, Ibu Hafzah, dan Bapak Riko Wardana mengaku bahwa interaksi terjalin tidak hanya dengan kelompok Islam melainkan juga dengan masyarakat non Muslim. Fenomena ini menjadi sebuah realitas baru di era saat ini bahwa Salafi tidak membatasi diri dari aktivitas-aktivitas sosial-keagamaan. Mereka justru melibatkan diri dalam mencapai sebuah kedamaian dengan bergabung dalam sebuah Paguyuban masyarakat dalam melakukan penjagaan wilayah dari ancaman-ancaman kriminalisasi. Konsep ini merupakan interpretasi konsep al-wara wa al bara yang mengacu pada konteks, seperti konsep Wasati yang lebih berfokus pada berdakwah untuk mengajak non-Muslim untuk masuk Islam dengan cara-cara yang lembut dan mudah diterima secara nalarlogika (Shavit, 2014).

Bahwa terbukanya gerakan dakwah Salafi dengan dunia luar, bahkan terbangunnya interaksi yang baik dengan masyarakat Muslim maupun non Muslim menunjukkan tidak ada lagi aktivitas ekstrim yang dilakukan oleh kelompok Islam Salafi. Pertama, kelompok Islam Salafi sadar bahwa terlepas dari puritanisme, kelompok Salafi harus membaur dan membangun hubungan baik dengan masyarakat sekitar dengan tidak membatasi diri dari dialog-dialog dengan masyarakat luar (Chaplin, 2018). Kedua, Salafi mulai menggunakan fasilitas industri 4.0 dalam berdakwah, bersosial, dan berekonomi seperti yang telah diungkapkan oleh beberapa informan. Ketiga, Salafi di Kota Metro telah mampu membangun hubungan baik dengan masyarakat Kristen dalam aktivitas penjagaan wilayah dengan membentuk sebuah Paguyuban. Realitas sosial tersebut merupakan gerakan Salafi di Kota Metro. Selain untuk membangun pondasi kuat dalam berIslam, juga memperluas aspek dakwah di masa sekarang dengan memanfaatkan ruang dan fasilitas yang tersedia. Ini berarti, Salafi di kelurahan Purwoasri tidak hidup sebagai kelompok yang membatasi diri (tertutup) dari persinggungan publik dan konservatif, melainkan mampu mengikuti perubahan masa dan membangun hubungan baik dengan non-Muslim.

Interaksi sosial dan keagamaan merupakan salah satu aktivitas penting yang harus dibangun dalam melakukan dakwah. Hubungan yang baik dengan masyarakat dan agama lain akan mudah mempercepat ajaran Salafi masuk ke dalam lapisan masyarakat. Integrasi dengan komunitas dan elemen masyarakat, tidak hanya sebagai upaya untuk meminimalkan penolakan melainkan juga sebagai strategi dakwah yang relevan pada saat ini (Abidin and Hafizah, 2019). Hadirnya teknologi juga membuat gerakan penyebaran Islam dapat berinteraksi dengan dunia yang lebih luas secara intens sehingga bermunculan varian Islam progresif-ideologis, politik-radikalis dan umum populer (Zuhri, 2016).

Penelitian ini menunjukkan realitas baru dalam aktivitas dakwah Islam Salafi yaitu dengan menggunakan pendekatan sosial keagamaan. Pertama, Salafi menyadari bahwa interaksi sosial yang terbangun baik akan memudahkan gerakan dan ajaran Salafi dapat diterima publik. Kedua, keterbukaan dengan masyarakat menciptakan kekuatan baru dalam mempertahankan eksistensi dan wilayah Salafi, misalnya kerjasama yang dibangun dengan masyarakat Kristen. Dan, ketiga, penggunaan media sosial dalam berdakwah lebih dapat diterima publik sebagai kajian agama dan mampu meminimalisir bahaya untuk dakwah.

Pergerakan yang semakin fleksibel membuat Salafi leluasa dalam melakukan gerakan dakwah, baik dengan lisan, hikmah, qolam, nikah, hal, maal, rikhlah, dan qolbi. Metode-metode dakwah tersebut saat ini telah banyak dilakukan dengan memanfaatkan fasilitas teknologi yang tersedia untuk menjangkau lapisan-lapisan terkecil. Analisis ini sering kali menghadirkan perspektif keluarga Salafi 
dan masyarakat sekitar, tanpa melibatkan sektor pemerintah sebagai pihak pengambil kebijakan sosial-politik. Hadirnya pemerintah menjadi kontrol sosial-politik yang memberi batasan hukum pada aktivitas organisasi keagamaan yang keras, ekstrim, dan brutal.

Penelitian gerakan dakwah Salafi merupakan hal penting dalam mengungkap bahwa apakah ada upaya peleburan gerakan Salafi dengan kebudayaan lokal ataukah masih mempertahankan usaha-usaha konvensional. Pensejajaran Salafi dengan kelompok-kelompok Muslim ekstrim membuat pendeskreditan Salafi terjadi di berbagai tempat. Kecenderungan pada bayang-bayang konsevativisme dan ekslusivitas menciptakan asumsi negatif terus terbangun di dalam setiap individu maupun kelompok Muslim lainnya. Kecenderungan tersebut membuat tidak terbangunnya narasi perdamaian antara umat Muslim Salafi dengan kelompok lainnya dan/atau dengan non-Muslim. Kondisi ini membuat opini negatif terkait Salafi mengkristal menjadi sebuah kebencian, yang berarti sebuah proses konstruksi sosial yang tidak terbangun dengan baik dan menciptakan ketegangan.

\section{Kesimpulan}

Tenyata dakwah Salafi secara praktik tidak sepenuhnya melakukan aktivitas radikal dan merujuk pada kekerasan, justru saat ini Salafi melakukan dakwah melalui cara yang damai dengan masuk ke dalam ruang sosial kemasyarakat dan ruang keagamaan, baik secara langsung (konvensional) maupun menggunakan fasilitas digital. Temuan penelitian ini (berbeda dengan temuan penelitian sebelumnya) mengungkap bahwa asumsi publik tentang Salafi tidak dapat digeneralisir ke dalam semua kelompok Salafi (terkait konservatisme, radikal, pengasingan diri dan ekslusif) karena Salafi menyebar dan berkembang dalam banyak varian. Di masa modern saat ini mereka memiliki misi untuk mengembalikan ajaranajaran Islam yang otentik seperti yang telah dipraktikkan oleh Nabi dan tiga generasi awal Islam (Duderija, 2007). Bahkan ditemukan sebuah realitas baru bahwa kelompok Salafi di Kota Metro juga membangun ruang intensif dengan kelompok Islam lainnya dan umat Kristiani dalam sebuah Paguyuban untuk melakukan penjagaan dari aktivitas kriminalisme. Faktor interaksi sosial dan keagamaan tersebut memberikan dampak signifikan pada eksistensi Salafi, kenyamanan dan keamanan dalam ibadah dan gerakan dakwah, ekonomi, dan sosial. Fenomena ini menunjukkan bahwa Salafi pada saat ini lebih fleksibel dan terbuka pada setiap perubahan dan persinggungan dengan publik.

Konsep sosial-keagamaan Salafi dalam penelitian ini mampu membangun hubungan baik dan memperbaiki citra negatif masyarakat Salafi dari pandangan publik. Hubungan baik tersebut, selain berpengaruh pada akses penyebaran ajaran Salafi, juga menciptakan kestabilan ekonomi keluarga Salafi karena mereka mempunyai banyak kesempatan untuk melakukan aktivitas ekonomi dengan masyarakat luas secara face to face maupun secara online. Kepercayaan masyarakat dengan kelompok Islam Salafi juga mulai terbangun, sehingga terciptalah hubungan baik dengan Muslim dan non-Muslim sekitarnya. Aktivitas ini sekaligus merespon asumsi publik dengan gerakan-gerakan yang fleksibel dalam membangun sebuah peradaban.

Studi ini terbatas pada perspektif masyarakat Salafi di Kota Metro belum terintegrasikan dengan perspektif masyarakat Salafi di daerah lainnya. Mengingat kelompok Salafi yang satu dengan lainnya tidak sepenuhnya memiliki kesamaan, maka mengintegrasikan dengan perspektif Salafi di lain daerah akan memungkinkan untuk mendapatkan pemahaman yang lebih dalam dan relevan pada kondisi sosial-keagamaan di tempat tersebut. Cara ini memungkinkan untuk mendapat sebuah gambaran umum tentang gerakan Salafi dan meluruskan asumsi masyarakat terkait Islam Salafi. Oleh karena itu, dibutuhkan sebuah penelitian lanjutan yang membahas perspektif Salafi di lain 
daerah dengan mendemonstrasikan gerakan dan pengalaman mereka dalam menjalankan aktivitas sosial dan dakwah. Dengan cara ini memungkinkan untuk ditemukannya akar sebuah permasalahan terkait gerakan Salafi yang lebih relevan.

\section{Ucapan Terima Kasih}

Diucapkan terimakasih banyak kepada koresponden dan pihak-pihak terkait dalam penelitian ini, sehingga peneliti mampu menyelesaikan penelitian ini dan menampilkan realitas baru dari aktivitas sosial-keagamaan komunitas Salafi.[]

\section{Daftar Pustaka}

Abdullah, K. and Salleh, M. A. (2015) 'Conceptualizing jihad among southeast Asia's radical Salafi movements. Journal for the Study of Religions and Ideologies, 14(42).

Abidin, M. Z. and Hafizah, Y. (2019). Conflict and Integration in The Salafi-Wahabi Purification Movement in South Kalimantan. Wawasan: Jurnal Ilmiah Agama dan Sosial Budaya.

Amin, S. J. (2020). Movement of islamic organization and its impact on radical perception with supply chain management in the digital era. International Journal of Supply Chain Management, 9(2).

Arifin, F. (2019). Mubalig Youtube Dan Komodifikasi Konten Dakwah. alBalagh/ : Jurnal Dakwah dan Komunikasi.

Armfield, G. G. and Holbert, R. L. (2003). The Relationship Between Religiosity and Internet Use. Journal of Media and Religion.

Bourdieu, P. (2018). The forms of capital. Dalam The Sociology of Economic Life, Third Edition.

Brown, J. A. C. (2015). Is Islam easy to understand or not?: Salafis, the democratization of interpretation and the need for the ulema. Journal of Islamic Studies.
Chaplin, C. (2018a). Salafi activism and the promotion of a modern Muslim identity: Evolving mediums of da'wa amongst Yogyakartan university students. South East Asia Research, 26(1).

Chaplin, C. (2018b). Salafi Islamic piety as civic activism: Wahdah Islamiyah and differentiated citizenship in Indonesia. Citizenship Studies, 22(2).

Chaplin, C. (2020). Communal Salafi learning and Islamic selfhood: Examining religious boundaries through ethnographic encounters in Indonesia. Ethnography, 21(1).

Damir-Geilsdorf, S., Menzfeld, M. and Hedider, Y. (2019). Interpretations of al-wala' wa-l-bara' in everyday lives of Salafis in Germany. Religions.

Duderija, A. (2007). Islamic groups and their world-views and identities: Neotraditional Salafis and progressive Muslims. Arab Law Quarterly.

Becker. (2009). “Gaining Knowledge”; Salafi Activism in German and Dutch Online Forums. Masaryk University Journal of Law and Technology, 3 (1).

Griffel, F. (2015). What Do We Mean by "Salafi"? Connecting Muhammad Abduh with Egypt's Nur Party in Islam's Contemporary Intellectual History. Welt des Islams.

Halim, N. A. (2015). Penggunaan Media Internet di Kalangan Remaja Untuk Mengembangkan Pemahaman Keislaman. Risalah.

Hellmich, C. (2008). Creating the ideology of Al Qaeda: From hypocrites to SalafiJihadists. Studies in Conflict and Terrorism.

Horii, M. (2019). Historicizing the category of "religion" in sociological theories: Max Weber and Emile Durkheim. Critical Research on Religion, 7(1), hal. 24-37.

ICG (2004). Indonesia Backgrounder: Why 
Salafism and Terrorism Mostly Don't Mix. International Crisis Group Asia Report.

Jahroni, J. (2018). Ritual, Bid'ah, and the negotiation of the public sphere in contemporary Indonesia. Studia Islamika.

Kagermann H.; Wahlster, W.; Helbig, J. (2013). 'Germany - Industrie 4.0'. Final report of the Industrie 4.0 WG.

Kagermann, Wahlster, W. and Helbig, J. (2013). Recommendations for implementing the strategic initiative INDUSTRIE 4.0. Final report of the Industrie 4.0 WG.

Kretschmer, D. and Leszczensky, L. (2021). In-Group Bias or Out-Group Reluctance? The Interplay of Gender and Religion in Creating Religious Friendship Segregation among Muslim Youth. Social Forces.

Kursani, S. (2018). Salafi pluralism in national contexts: the secular state, nation and militant Islamism in Kosovo, Albania, and Macedonia. Journal of Southeast European and Black Sea, 18 (2).

Kusmanto, T. Y., Fauzi, M. and Jamil, M. M. (2015). Dialektika Radikalisme Dan Anti Radikalisme Di Pesantren. Walisongo: Jurnal Penelitian Sosial Keagamaan.

Leszczensky, L. and Pink, S. (2017). Intra-and inter-group friendship choices of christian, Muslim, and non-religious youth in Germany. European Sociological Review, 33(1).

Lin, N. (2019). Building a network theory of social capital. Dalam Social Capital, Social Support and Stratification: An Analysis of the Sociology of Nan Lin.

Mahanani, P. A. R., Abdullah, I. and Noviani, R. (2019). Estetisasi Jilbab Syar'i Jama'ah Salafi: Studi Kasus di Pondok Pesantren Imam Muslim Kota Kediri. JSW (Jurnal Sosiologi Walisongo), 3 (1).
Nashirudin, M. (2017). Interaksi Simbolis Pondok Pesantren Salafi Dan Masyarakat. Epistemé: Jurnal Pengembangan Ilmu Keislaman, 12 (1).

Norlen, T. C. (2020). The impact of covid-19 on Salafi-jihadi terrorism. Connections, 19 (2).

Nurani, S. (2019). Salafî Women And Islamic Movements: The Case of Salafism in Jama'ah al-Khidhir. ULUL ALBAB Jurnal Studi Islam.

Nurdin, N. (2016). Radicalism on World Wide Web and Propaganda Strategy. Al-Ulum.

Nurish, A. (2020). The Myth of Religious "Radicalism". Al-Albab.

Omelicheva, M. Y. (2016). Islam and power legitimation: instrumentalisation of religion in Central Asian States. Contemporary Politics.

Othman Alkaff, S. H. Bin and Bin Jani, M. H. (2021). Contemporary Salafism in Singapore. Journal of Muslim Minority Affairs, 41(1).

Pall, Z. and Pereiro, A. P. (2020). Salafi Islam in Cambodia: Institution Building, Transnational Networks and Patterns of Competition in a Muslim-Minority Context. Welt des Islams, 60 (2-3).

Putnam, R. (2001). Social capital: Measurement and consequences. Canadian Journal of Policy Research.

Rahmatullah, Y. (2017). Radicalism, Jihad and Terror. Al-Albab.

Redjosari, S. M. (2019). Salafi dan Stigma Sesat-Radikal. ISLAMICA: Jurnal Studi Keislaman.

Rohmaniyah, I. and Woodward, M. (2012). Wahhabism, Identity, and Secular Ritual: Graduation at an Indonesian High School. Al-Jami'ah: Journal of Islamic Studies, 50 (1).

Saalfeld, J. (2019). On the Divergent Trajectories of African Islamism: Explaining Salafi Non-Radicalisation 
in Zanzibar: Die unterschiedlichen Pfade des Islamismus in Afrika: $\mathrm{Zu}$ den Ursachen Salafistischer Nichtradikalisierung in Sansibar. Africa Spectrum, 54(3).

Saepullah, U. (2020). E-Dakwah Islam Digest Republika.Co.Id. di Indonesia. Ilmu Dakwah: Academic Journal for Homiletic Studies.

Saparudin, S. (2017). Salafism, State Recognition and Local Tension: New Trends in Islamic Education in Lombok. Ulumuna, 21 (1).

Setiawan, W. and Midia, F. G. (2020). Community Acceptability To The Salafi Movement. AKADEMIKA: Jurnal Pemikiran Islam, 24 (2).

Shavit, U. (2014). Can Muslims Befriend Non-Muslims? Debating al-walâ waal-barâ (Loyalty and Disavowal) in Theory and Practice. Islam and Christian-Muslim Relations, 25(1), hal. 67-88.

Solahudin, D. (2019). Reconstructing Da'wah of Salafi in Shaikh Muhammad Al-Ghazali Works. Ilmu Dakwah: Academic Journal for Homiletic Studies, 13 (2).

Staunton, D. (2008). The Clash of Identities: An Analysis of the Causes of Salafi Jihadi Terrorism with Reference to Jamaah Islamiyah. Studies in Ethnicity and Nationalism.

Sunarwoto (2016). Salafi Dakwah Radio: A Contest for Religious Authority. Archipel, (91).

Taufik, M. and Taufik, A. (2020). Hijrah As A Trend Of Islamic Pop Culture Among Students In Lombok, West Nusa Tenggara. Teosofia.

Umar, M. S. and Woodward, M. (2020). The Izala effect: unintended consequences of Salafi radicalism in Indonesia and Nigeria. Contemporary Islam, 14(1).

Wagemakers, J. (2018). Jihadi-Salafism in Jordan and the Syrian conflict:
Divisions overcome unity. Studies in Conflict and Terrorism, 41 (3).

Wahib, A. B. (2017). Being pious among Indonesian Salafis. Al-Jami'ah.

Wahid, D. (2015). Nurturing Salafi manhaj A study of Salafi pesantrens in contemporary Indonesia. Wacana.

Wiktorowicz, Q. (2000). The Salafi movement in Jordan. International Journal of Middle East Studies.

Wiktorowicz, Q. (2006). Anatomy of the Salafi movement. Studies in Conflict and Terrorism.

Wilonoyudho, S., Salim, L. A. and Muhtaram, A. (2020). The perspective of Puritan moslem on the family planning program: The case of Salafimovement in Semarang, central Java, Indonesia. Indian Journal of Forensic Medicine and Toxicology, 14 (4).

Yakin, A. U. (2018). Salafi Dakwah and the Dissemination of Islamic Puritanism In Indonesia: A Case Study of the Radio of Rodja. Ulumuna, 22 (2).

Zaenuri, A. and Yusuf, H. (2019a). Salafi's Da'wah and the Phenomenon of Religious Piety among Hijrah Artists. Millati: Journal of Islamic Studies and Humanities.

Zaenuri, A. and Yusuf, H. (2019b). Salafi's Da'wah and the Phenomenon of Religious Piety among Hijrah Artists. Millati: Journal of Islamic Studies and Humanities, 4(2).

Zuhri, S. (2016). The Islamic Public Sphere/ : Manifestations Of Islam In The Contemporary Indonesia. Millah, XI (2), hal. 453-472. 